\title{
CENTRAL AND SOUTH - EASTERN EUROPE BANKING SECTORS IN THE SUSTAINABLE DEVELOPMENT FUNCTION
}

\author{
Nenad Vunjak ${ }^{1}$, Miloš Dragosavac ${ }^{2}$, Jelena Vitomir ${ }^{3}$, Petra Stojanovićc
}

date of paper receipt:

26.03.2020.

Review form date of sending to review:

29.03.2020.

doi: 10.2478/eoik-2020-0009 date of review receipt:

07.04.2020.

UDK:

339.732.4:330.34(4-11+4-12)

1 Professor of the Modern Business School in Belgrade (Serbia) and the Faculty of Business Economics in Bijeljina BiH

2 Assistant professor, Modern Business School in Belgrade, Serbia

3 Assistant professor ,University of Business Studies in Banja Luka, BiH

4 Master of Economic Sciences, Agricultural School in Bijeljina, BiH

\begin{abstract}
Changes in banking sectors with the onset of the global financial crisis were related to: globalization, sector deregulation, technological change and financial innovation. Structural changes within banking services (at the end of the 20th century) relate to: the consolidation of banks, the merging of banking and non-banking financial institutions and their competition with one another. Significant place in the part of sustainable development belongs to bank performance, vision and mission of banks. The corporate vision of banks should be the "framework" for the future development of a bank. The corporate mission should be a "roadmap" to the realization of the bank's vision and an expression of the business philosophy of the bank in question.

It is of particular importance for the banking sectors of the CEE countries to define: the vision, the mission, the situational analysis and the planned long-term goals of the bank. With the advent of the global financial crisis, the financial activity of banks in the Central and Southeastern European region decreased, as the number of attractive fusion and acquisition banks in the region concerned was reduced.

The aim of the research is to determine the importance of the vision, mission and clearly set goals in banks, where the analysis of banking sectors in 13 countries over a period of 11 years was carried out. The analysis of GDP and its growth in the period from 2008 to 2018 indicates a dynamic growth in the countries of Central Europe and some countries of Southeast Europe. The analysis of the assets of the banking sector and its share in GDP indicates the dominant participation of the countries of Central and Southeastern Europe that are members of the European Union relative to the candidate countries for EU member states. Analysis of the banking sector of the influx countries shows that more than $70 \%$ of the banking market in Southeast European countries is influenced by foreign highly developed banking groups. Sustainable development can only be achieved through the active joint action of the banking sectors of the Central and Southeast European countries.
\end{abstract}

\section{Keywords:}

Happiness Index, Sleep Economics, Sleep Deprivation, Inadequate Sleep

\section{JEL: G21, F60}




\section{INTRODUCTION}

The factors of change in banking with the advent of the global financial crisis were related to: 1) globalization 2) deregulation 3) technological change and 4) financial innovation (Vunjak N., Ćurčić U. \& Kovačević Lj. 2013). Globalization of the financial market implies that there is universal business, a high degree of competitiveness between banks and non-banking financial institutions, the consolidation and restructuring of banks and the financial market. Globalization also involves disintermediation in bank operations whereby banks are conditioned to accept lower fees for their services, to take greater risks, and to expand their customers through non-traditional banking operations (Cocris V. \& Nucu E., (2013). ). Banking deregulation puts banking regulation aside and only respects the necessary regulation to conduct banking transactions. Minimum regulatory requirements relate to: a) protecting the assets of the population and confidence in the banking sector b) security and reliability of the banking sector c) adequacy of banks' capital d) timely financial reporting and application of international accounting standards e) creating conditions for bank competition f) greater accountability bank management. (Koch W. T., \& MacDonald S. S., 2003).

Technological changes are present on a daily basis in the banking business, so that banks, using modern technology, can daily monitor and change their balance sheet positions (assets and liabilities structure) and track changes in their positions (Pere, E. 2015.). Technological changes have enabled banks to:

a) increasing economies of scale b) facilitating consolidation and integration with competition

c) creation of new banking products and services d) more efficient risk management for banks

e) more efficient and faster flow of information, marketing of services and distribution of products and services $\mathrm{f}$ ) securities trading $\mathrm{g}$ ) innovations in the field of financial engineering (financial derivatives) h) increase of efficiency and profitability of work i) creation of virtual banks through internet banking (Vunjak N., Radović M., Vitomir J. \& Štrbo S. 2019)

A special place in the part of the new banking technology belongs to internet banking, which created the conditions for:

1) perfect awareness of service users,

2) reducing the cost of banking transactions,

3) developing cooperation with users of banking services,

4) quick insight into cash balances on accounts and collection of securities due,

5) authorization of automatic payments,

6) delaying data of IT applications, etc. (Curcic U. 2003.)

Electronic banking has brought banks comfort in business, increased trust between banks and clients and risks associated with lagging behind in the application of modern banking technology. Financial innovations in banks are the result of changes in legal regulation, operational and strategic management of banking operations. Innovations in banking are mostly related to the forms of new securities, new banking services, changing organizational forms, channels of distribution of banking products and services (Achim, V., Borlea,N.,\& Mare,C. 2015).

Structural changes within banking services have emerged in the last decades of the 20th century, which include: a) bank consolidation b) the association of banking and non-banking financial institutions c) competition between banks and non-banking financial institutions (Sherstnev, M. A. 2019.) Modern financial services are present in the financial market not only by banks but also by insurance companies and pooled funds. Due to the presence of structural changes, a large number of banks have adopted a new management philosophy to counteract the effects of the financial crisis. Structural changes in banking services have not been overlooked by banks in the countries of Central, Eastern and Southeastern Europe, all with the aim of sustainable economic and financial development (Andries, A.M.2011.) 


\section{CORPORATE PERFORMANCE OF BANKS IN THE SUSTAINABLE DEVELOPMENT FUNCTION}

According to modern theory and practice, corporate performance of banks should mean the achieved results, quantity and quality of bank operations, which relates to:

a) profitability rate b) asset quality c) bank liquidity rate. The word "performance" in the general sense represents functional ability, performance, execution and achievement (Dragosavac M. 2013.)

The performance of banks represents a "mirror" of their value, their success, their size, their efficiency and effectiveness in business. In cases where banks' performance is viewed as a peer group of banks, they can then be classified as low, medium and high performing. Poor performance is indicators that tend to decrease from average to minimum. Medium performance represents indicators achieved by banks at the average bank group level. High performance of banks is an indicator of the highest level of success of a bank's business (its liquidity, solvency and profitability) (Andries A.M. \& Căpraru B., 2012.)

Expressing the performance of banks is done to compare them with the performance of other banks. In banking practice so far, the following banks' performance is most often present:

a) finance b) marketing c) management d) business philosophy e) employees $\mathrm{f}$ ) business culture and style of behavior $\mathrm{g}$ ) business reputation and reputation $\mathrm{h}$ ) bank image and goodwill (Curcic $\mathrm{U}$. 2003.)

Banks' financial performance is the most prominent in bank analyzes and relates to aspects of their cost and operational efficiency. Banks' financial performance includes: a) front and back banks b) leverage and allocation of bank assets c) quality of bank assets d) control of the bank's general expenses (Košak, M., Zajc, P. \& Zorić, J. 2009.) It is characteristic of banks that have high corporate performance that their manager has a clear strategic direction that they achieve through strategic planning. Banks with high corporate performance to maintain strategic direction face considerable pressure from the environment in the face of change. Such banks have a good management team that quickly accepts change and, through the life cycle stages of banking products and services, make changes. The main features of high performing banks are related to profit maximization, cost control and good management ( Dragosavac M. 2019.)

The strategy for the development of banks' corporate performance is defined by applying a swot analysis (opportunity, strength, threats and weakness) based on: a) low cost strategies b) strategies for differentiating banking products and services c) niche strategies (market segments) (Barth R., Caprio G. \& Levine R.,2004)

The process of choosing a strategic development of a bank's corporate performance involves several stages. The first stage in the strategic process is about knowing the priority goals of the bank and their time constraints. The second stage is related to the analysis of outstanding issues regarding the impediment and possible realization of the development strategy, whereby it is necessary to carry out a real valuation of the bank's aggregates (assets) and resources (liabilities). The third phase concerns the choice of corporate development strategy and target part of the financial market. Within this phase, in addition to determining the revision of the target corporate strategy, the final variants of the strategic direction of the bank's development are determined (Buterin V.; Škare, M. \& Buterin, D. 2017)

A special place in defining the corporate performance of banks belongs to the vision and mission of bank development. The vision should be a "framework" for the future development of the bank. The vision creation starts from the following factors: a) achieved, achievable and realistic vision of the bank b) creations, inspirations and motivations in defining the vision of the bank c) benefits of the bank's vision on the users of its services (Poghosyan, T. \& Poghosyan, A. 2010.)

A clear corporate vision of the bank encourages and encourages the bank's employees to be more engaged in achieving that vision. The bank's corporate vision often conflicts with the strategic development direction of the bank. The practice of the most developed banks so far shows that the vision of development is realized at the corporate level and that it is a precondition for determining the strategic business direction of the bank. The strategic business direction is defined by the bank's 
management for the bank as a whole and for each business unit (profit center) individually.

The corporate vision of the bank's development is the basis for defining the bank's mission. A bank's vision is a way of successively realizing a bank's development vision. The mission of the bank is to integrate the individual goals and objectives of the organization of the bank into one whole, creating positive synergetic effects. Unlike a corporate vision that provides a "framework" for choosing a bank's development, the corporate mission accomplishes the bank's development goals exactly as management wants the bank to be in the future (Pervan M., Pelivan I., \& Arnerić J.2017.)

A corporate mission can be defined as a "framework" for the bank's own objectives and as an expression of the bank's business philosophy. The process of creating and redefining a bank's mission should first go from considering the results of a situational analysis of the bank and its environment. Then it is necessary to define strategic, tactical (annual) and operational goals, as well as their interdependence. The bank's mission should be broad enough to encompass all the alternatives available to the bank's management. The bank's mission should have a decisive influence on the long-term strategic planning process (up to 5 years) and on the operational (current and monthly) planning process of the bank. After accepting the bank's mission, it should be binding on the supervisory authorities, the bank's management, the bank's employees and the bank's investors. Banking practice shows that without a clearly defined mission, it is not possible to develop a collision planning process for a bank (Garciya-Marco T. \& Robles-Fernandez M.D.2013) .

There are objectives in banks' operations related to profit (rate of return on total assets), dividend (rate of return on share capital) increase in participation in the financial market risk diversification, banking innovations, etc. The business objectives of the bank should be defined after considering the environment, the financial market and the mission of the bank if sustainable development is to be achieved. The business goals of the bank should be based not only on the interests of the owners (shareholders), the bank's managers, but also on the market, ie the needs and requirements of the customers of banking products and services. It is in the context of sustainable development that the task of the bank's management should be to transform the bank's mission into specific goals and objectives, through which the bank's mission will be supported in the long term and operationally. The business goals of the bank can be divided into: a) financial goals b) management goals c) marketing goals of the bank (Babihuga R.,2007)

It is of particular importance for the banking sectors of Central and South-East European countries to define the bank's vision, mission, situational analysis and planned long-term goals for sustainable development (Barjaktarović, L., Paunović, M. \& Ječmenica, D. 2013) It is a fact that sustainable development in the conditions of globalization and the presence of the global financial crisis is impossible without strict implementation of the strategic corporate vision and mission of the banks. Managing the aggregates and resources of the balance sheet, as well as the income and expenses in the income statement of banks, is a condition for the long-term sustainable development of not only the banking sector but also other economic and non-economic sectors. The macro indicators of gross domestic product (GDP), foreign direct investment (FDI), exports and imports are related to the banking sector and sustainable development (Cocris V. \& Nucu E., 2013.)

\section{ANALYSIS OF THE SITUATION AND DEVELOPMENT OF THE BANKING SECTORS OF CENTRAL AND SOUTHEAST EUROPE}

The banking market of the countries of Central and South-Eastern Europe compared to the European Union can be said to be relatively weak and still underdeveloped. The leading banking groups of Central and Southeast European countries experienced an expansion in the second decade of the 21 st century, which can be seen from the size of the banking assets and capital owned by foreign banks. This claim can be substantiated by the fact that over $70 \%$ of the banking market in these countries is influenced by foreign banking groups (Dmitrovic M., Dobrota M. \& Knezevic S.,2016) 
Analyzes show that with the advent of the global financial crisis and recession, the financial activity of Western European banks in the region of Central and Southeast European countries has decreased. This trend is still largely present, as the number of attractive banks that could be purchased has decreased. Due to slower overall economic growth, there is a liquidity deficit in the banking sector (Raszkovski A. \& Bartniczak B. 2019).

The analysis of the situation of the banking sectors covers 13 countries of Central and Southeastern Europe, which are divided into three groups. The first group includes countries that have been members of the European Union for a number of years (Czech Republic, Slovakia, Slovenia, Poland and Hungary). These are the most developed countries of Central and Southeastern Europe. The second group includes Southeast European countries that are also members of the European Union but at a lower financial level of development (Croatia, Bulgaria and Romania). The third group also includes the non-EU countries of Southeast Europe, which aspire to become and are still in the process of transition (Serbia, Bosnia and Herzegovina, Montenegro, Macedonia and Albania). The third group of countries can be said to have the lowest level of economic and economic development. These countries are also called Western Balkan countries. They are characterized by low economic growth as a consequence of the lack of their own production (most of them are industrial lone businesses). With them, the cost of banking services is higher than in other parts of Europe. Interest rates are expressive for cash loans in local currencies. The financial market can be said to be high risk, in the presence of political instability, high unemployment and high public debt that the countries concerned have towards their creditors. In most cases, there is a reciprocal link between the banking sectors and the economics of the social development of countries (Laidroo L., Männasoo K.,(2014)

The development of the banking sector is conditioned by a number of economic and demographic factors. A special place in the country's macroeconomic indicators belongs to: a) gross domestic product (GDP) b) exports c) imports d) foreign direct investment (FDI). Indicators are of particular importance for realistic planning (operational and strategic) and successful implementation of the economic policies of the countries concerned. Gross domestic product is particularly monitored for its percentage growth. For the purpose of balancing GDP in Central and Southeast European countries, its dynamics will be analyzed in the period from 2008 to 2018 (Mano-Bakalinov, V. 2016)

Table 1. GDP by defined groups of countries in the period 2008-2018 (billion EUR)

\begin{tabular}{|c|c|c|c|c|c|c|c|c|c|c|c|c|}
\hline & $\mathbf{2 0 0 8}$ & $\mathbf{2 0 0 9}$ & $\mathbf{2 0 1 0}$ & $\mathbf{2 0 1 1}$ & $\mathbf{2 0 1 2}$ & $\mathbf{2 0 1 3}$ & $\mathbf{2 0 1 4}$ & $\mathbf{2 0 1 5}$ & $\mathbf{2 0 1 6}$ & $\mathbf{2 0 1 7}$ & $\mathbf{2 0 1 8}$ \\
\hline \multicolumn{10}{|c|}{ GRUPA 1 } \\
\hline SVN & 37.0 & 35.0 & 36.0 & 36.0 & 35.0 & 35.0 & 36.0 & 37.0 & 40.4 & 43.0 & 45.7 \\
\hline SVK & 67.0 & 63.0 & 66.0 & 69.0 & 71.0 & 72.0 & 74.0 & 78.0 & 81.1 & 84.9 & 90.6 \\
\hline CZE & 154.0 & 142.0 & 150.0 & 156.0 & 153.0 & 150.0 & 148.0 & 160.0 & 176.6 & 191.9 & 207.3 \\
\hline POL & 363.0 & 311.0 & 355.0 & 370.0 & 382.0 & 389.0 & 412.0 & 451.0 & 426.0 & 466.0 & 495.5 \\
\hline HUN & 106.0 & 91.0 & 96.0 & 101.0 & 96.0 & 98.0 & 96.0 & 100.0 & 113.7 & 124.0 & 131.1 \\
\hline \multicolumn{10}{|c|}{ GRUPA 2 } \\
\hline HRV & 48.0 & 44.8 & 44.4 & 44.2 & 43.7 & 43.3 & 42.9 & 44.1 & 46.7 & 49.0 & 51.5 \\
\hline BGR & 35.0 & 34.9 & 36.1 & 38.5 & 39.9 & 39.9 & 42.1 & 44.5 & 48.1 & 51.7 & 54.9 \\
\hline ROU & 140.0 & 118.3 & 124.4 & 131.5 & 131.7 & 142.2 & 149.3 & 161.8 & 170.0 & 188.0 & 203.3 \\
\hline \multicolumn{10}{|c|}{ GRUPA 3 } \\
\hline SRB & 33.0 & 29.0 & 28.0 & 31.0 & 30.0 & 33.0 & 35.0 & 38.0 & 38.3 & 39.2 & 42.7 \\
\hline BIH & 13.0 & 12.0 & 13.0 & 13.0 & 13.0 & 14.0 & 14.0 & 15.0 & 16.9 & 16.02 & 16.73 \\
\hline MNE & 3.1 & 3.0 & 3.1 .0 & 3.2 & 3.1 & 3.3 & 3.4 & 3.5 & 4.4 & 4.7 & 5.5 \\
\hline MKD & 8.3 & 9.9 & 9.4 & 9.4 & 10.5 & 9.7 & 10.8 & 11.3 & 10.67 & 11.34 & 12.67 \\
\hline ALB & 9.0 & 9.0 & 9.0 & 10.0 & 10.0 & 10.0 & 11.0 & 12.0 & 11.8 & 13.06 & 15.06 \\
\hline
\end{tabular}

Source: (Central Bank Publications of the analyzed countries) 
The table below shows that Poland, the Czech Republic, Romania, Hungary and Slovakia had high levels of GDP. Bulgaria, Croatia, Slovenia and Serbia had twice the GDP level. Extremely low levels of GDP were recorded in Albania, Bosnia and Herzegovina, Macedonia and Montenegro. GDP growth from 2014 to 2018 is present in most of the analyzed countries. GDP growth has had different trends, as some countries have experienced a negative growth rate.

Table 2. Annual GDP growth for the analyzed group of countries for the period 2008-2018 (\%)

\begin{tabular}{|c|c|c|c|c|c|c|c|c|c|c|c|c|}
\hline \multicolumn{10}{|c|}{ GRUPA 1 } \\
\hline SVN & 3.5 & -7.8 & 1.2 & 0.6 & -2.3 & -2.0 & -0.5 & 1.5 & 3.1 & 4.9 & 4.3 \\
\hline SVK & 5.8 & -4.9 & 4.4 & 3.0 & 1.8 & 0.9 & 2.2 & 3.0 & 3.1 & 3.2 & 4.3 \\
\hline CZE & 3.1 & -4.4 & 2.3 & 1.8 & -0.9 & -0.9 & 2.3 & 2.4 & 2.4 & 4.5 & 2.9 \\
\hline POL & 5.1 & 1.7 & 3.9 & 4.5 & 1.9 & 1.6 & 3.1 & 3.3 & 3.1 & 4.8 & 5.2 \\
\hline HUN & 0.9 & -6.8 & 1.3 & 1.6 & -1.7 & 1.1 & 2.0 & 2.0 & 2.3 & 4.1 & 4.6 \\
\hline \multicolumn{10}{|c|}{ GRUPA 2 } \\
\hline HRV & 2.1 & -6.9 & -2.3 & -0.2 & -1.9 & -1.0 & -0.8 & 1.0 & 3.5 & 2.9 & 2.8 \\
\hline BGR & 6.2 & -5.5 & 0.4 & 1.8 & 0.6 & 0.9 & 2.0 & 3.5 & 3.9 & 3.8 & 3.5 \\
\hline ROU & 7.3 & -6.6 & -1.1 & 2.3 & 0.6 & 3.5 & 3.5 & 3.5 & 4.8 & 6.9 & 3.9 \\
\hline \multicolumn{10}{|c|}{ GRUPA 3 } \\
\hline SRB & 3.8 & -3.5 & 1.0 & 1.6 & -1.5 & 2.5 & 1.0 & 2.0 & 2.8 & 2.0 & 4.2 \\
\hline BIH & 5.7 & -2.8 & 0.7 & 1.0 & -1.1 & 1.9 & 1.5 & 3.5 & 2.8 & 3.2 & 2.9 \\
\hline MNE & 6.9 & -5.7 & 2.5 & 3.2 & -2.5 & 3.3 & 2.0 & 3.5 & 2.1 & 4.7 & 4.9 \\
\hline MKD & 5.5 & -0.4 & 3.4 & 2.3 & -0.5 & 2.7 & 3.8 & 3.9 & 2.4 & 0.2 & 2.7 \\
\hline ALB & 7.8 & 3.3 & 3.9 & 3.1 & 1.6 & 0.4 & 2.0 & 3.0 & 3.2 & 3.8 & 4.1 \\
\hline
\end{tabular}

In the first group of countries, Slovenia and Hungary recorded the largest negative GDP growth in 2009. The highest positive GDP growth was recorded by Poland in 2008 and Slovenia in 2017. The association of the group of countries had the highest negative GDP growth in 2009 in Bulgaria in 2008 and Romania in 2017. In the third group of countries, the highest negative GDP growth was recorded in 2009 by Montenegro and Serbia, while the highest positive growth was recorded by Albania in 2008 and Montenegro in 2018. Overall, a positive trend of GDP growth has been present in the Central and Southeastern European region since 2014, which is evidence that the negative impact of the global financial crisis has been reduced (mitigated) (Arestis, P., Ferrari Filho, F., \& Terra, F. H. B. 2018.)

In terms of banking sector, the countries of the region of Central and South-Eastern Europe are specific in their characteristics. The analysis of bank portfolio diversification shows that there is an increase in assets in the countries of Central Europe and partly in the countries of Southeast Europe! The strengthening of the bank's portfolio was partly halted by the global financial crisis. 
Table 3. Balance sheet (assets) of the banking sectors of the Central and South-Eastern European countries in the period 2008-2018 (million EUR)

\begin{tabular}{|c|c|c|c|c|c|c|c|c|c|c|c|c|}
\hline & $\mathbf{2 0 0 8}$ & $\mathbf{2 0 0 9}$ & $\mathbf{2 0 1 0}$ & $\mathbf{2 0 1 1}$ & $\mathbf{2 0 1 2}$ & $\mathbf{2 0 1 3}$ & $\mathbf{2 0 1 4}$ & $\mathbf{2 0 1 5}$ & $\mathbf{2 0 1 6}$ & $\mathbf{2 0 1 7}$ & $\mathbf{2 0 1 8}$ \\
\hline \multicolumn{8}{|c|}{ GRUPA 1 } \\
\hline SVN & 49,000 & 45,300 & 45,800 & 45,600 & 44,500 & 39,800 & 37,400 & 35,500 & 40,587 & 41,750 & 43,094 \\
\hline SVK & 62,838 & 53,028 & 54,695 & 55,775 & 58,086 & 59,554 & 62,742 & 67,546 & 71,351 & 77,632 & 81,726 \\
\hline CZE & 154,375 & 159,418 & 172,776 & 178,675 & 189,996 & 189,749 & 194,677 & 205,369 & 222,798 & 263,294 & 270,770 \\
\hline POL & 261,401 & 273,965 & 292,755 & 293,100 & 330,267 & 339,309 & 359,502 & 375,423 & 386,825 & 427,453 & 443,742 \\
\hline HUN & 125,212 & 124,888 & 121,268 & 111,934 & 107,899 & 104,589 & 101,652 & 104,339 & 109,204 & 120,108 & 123,506 \\
\hline \multicolumn{8}{|c|}{ GRUPA 2 } \\
\hline HRV & 50,619 & 51,788 & 53,028 & 54,096 & 53,045 & 52,126 & 52,688 & 52,543 & 52,440 & 61,265 & 64,698 \\
\hline BGR & 35,565 & 36,234 & 37,695 & 39,273 & 42,138 & 43,842 & 43,529 & 44,750 & 47,087 & 50,734 & 55,236 \\
\hline ROU & 85,190 & 86,202 & 89,906 & 90,925 & 91,451 & 91,096 & 90,483 & 92,196 & 94,196 & 93,739 & 99,751 \\
\hline \multicolumn{7}{|c|}{ GRUPA 3 } \\
\hline SRB & 21,632 & 24,362 & 25,984 & 27,732 & 27,775 & 27,485 & 27,352 & 28,177 & 29,140 & 28,540 & 31.677 \\
\hline BIH & 10,761 & 10,742 & 10,828 & 11,196 & 11,414 & 11,994 & 12,514 & 12,755 & 13,344 & 14,464 & 15,794 \\
\hline MNE & 3,309 & 3,025 & 2,944 & 2,809 & 2,808 & 2,959 & 3,136 & 3,471 & 3,790 & 4,100 & 4,407 \\
\hline MKD & 4,728 & 5,107 & 5,829 & 6,383 & 7,077 & 7,464 & 8,076 & 7,411 & 7,233 & 7,513 & 8,187 \\
\hline ALB & 6,737 & 6,424 & 7,139 & 8,063 & 8,626 & 9,164 & 9,231 & 9,600 & 10,407 & 10,964 & 11,772 \\
\hline
\end{tabular}

Source: (Central Bank Publications of the analyzed countries)

The analysis of the presented table shows that the growth of the balance sheet total of banks in the countries of Central and Southeastern Europe is present. In the first group of countries, Poland recorded the highest growth, while Slovenia recorded variable growth. In the second group of countries, Romania had the highest growth, while Bulgaria had the lowest growth. In the third group of countries, Serbia had the highest growth, while Montenegro had the lowest growth. The analysis shows that there are positive pictures banking sectors since 2014 and that this trend continues especially in 2017.

Table 4. Share of total assets in GDP of Central and South-Eastern European countries (\%)

\begin{tabular}{|c|c|c|c|c|c|c|c|c|c|c|c|c|}
\hline & $\mathbf{2 0 0 8}$ & $\mathbf{2 0 0 9}$ & $\mathbf{2 0 1 0}$ & $\mathbf{2 0 1 1}$ & $\mathbf{2 0 1 2}$ & $\mathbf{2 0 1 3}$ & $\mathbf{2 0 1 4}$ & $\mathbf{2 0 1 5}$ & $\mathbf{2 0 1 6}$ & $\mathbf{2 0 1 7}$ & $\mathbf{2 0 1 8}$ \\
\hline \multicolumn{10}{|c|}{ GRUPA 1 } \\
\hline SVN & 131.6 & 128.5 & 130.0 & 126.4 & 125.5 & 112.2 & 100.4 & 92.9 & 85.0 & 97.2 & 94.3 \\
\hline SVK & 97.4 & 84.1 & 83.0 & 80.9 & 81.7 & 82.6 & 83.4 & 86.5 & 88.1 & 91.4 & 90.2 \\
\hline CZE & 108.0 & 112.2 & 114.3 & 120.7 & 124.2 & 135.2 & 126.3 & 124.0 & 127.9 & 137.1 & 130.6 \\
\hline POL & 72.0 & 83.7 & 81.8 & 85.0 & 84.6 & 86.2 & 88.8 & 89.0 & 92.4 & 91.7 & 89.6 \\
\hline HUN & 118.6 & 133.1 & 126.9 & 126.0 & 112.1 & 107.7 & 100.4 & 96.1 & 97.0 & 96.9 & 94.2 \\
\hline \multicolumn{10}{|c|}{ GRUPA 2 } \\
\hline HRV & 107.5 & 115.1 & 120.9 & 123.9 & 121.8 & 120.8 & 122.7 & 120.2 & 115.5 & 125.1 & 125.6 \\
\hline BGR & 104.2 & 103.7 & 104.6 & 102.0 & 105.5 & 106.8 & 103.6 & 98.8 & 99.4 & 98.1 & 100.6 \\
\hline ROU & 66.0 & 72.7 & 73.6 & 70.5 & 69.0 & 64.7 & 60.6 & 58.7 & 56.3 & 49.8 & 49.1 \\
\hline \multicolumn{10}{|c|}{ GRUPA 3 } \\
\hline SRB & 64.7 & 84.1 & 92.8 & 88.1 & 93.8 & 83.2 & 85.0 & 85.4 & 83.4 & 72.7 & 74.2 \\
\hline BIH & 85.2 & 86.8 & 85.5 & 85.3 & 87.0 & 89.1 & 92.4 & 87.5 & 87.8 & 90.6 & 94.4 \\
\hline MNE & 106.7 & 100.8 & 95.0 & 87.8 & 90.6 & 87.0 & 89.6 & 88.7 & 89.1 & 66.4 & 80.1 \\
\hline MKD & 56.9 & 51.6 & 62.0 & 67.9 & 67.4 & 76.9 & 74.8 & 75.4 & 74.6 & 66.4 & 64.6 \\
\hline ALB & 76.6 & 76.6 & 76.8 & 81.8 & 85.6 & 87.6 & 91.5 & 91.2 & 93.7 & 83.8 & 78.2 \\
\hline
\end{tabular}

Source: (Central Bank Publications of the analyzed countries). 
Analyzes show that the upward trend in the balance sheet share in GDP in the period 2008 to 2017 was present in: the Czech Republic, Poland, Croatia, Serbia, Bosnia and Herzegovina, Macedonia and Albania (Stanić. S., \& Račić Ž., 2019.)

A negative trend was present in countries: Slovenia, Slovakia, Hungary, Bulgaria, Romania and Montenegro. Despite the negative trend, the share of total assets in GDP is still higher in a number of EU Member States than in Southeast European (Western Balkan) candidate countries.. This trend was significantly influenced by the level of development of the economy and banking sector of the countries concerned.

\section{CONCLUSION}

Certain factors of change in the banking sector have had a positive impact, such as innovation and technological change, while the globalization process has had a negative impact, especially with the onset of the global financial crisis. Bank performance varied widely across countries, showing all its strengths in the highly developed countries of the European Union. In addition to defining the strategic direction of bank development, the implementation of swot analysis, the vision and mission of banks, as well as the strategy for the long-term development of the banking sectors, were particularly emphasized.

No difference the fact that the banking sectors represent the most important financial institutions that play an important role in the development of the economic sector, their participation is diminished in the global financial market with the advent of new financial institutions in the provision of services. Such financial institutions include: insurance companies, investment funds, pension funds and leasing companies. The decline in the market share of the banking sectors is the result of increased competition and reduced profits. Recently, there are more and more cases where banks in addition to providing banking services are engaged in providing insurance and leasing services, stockbroking, as well as investment and pension funds.

Banks can be said to play the most significant role in mediating and taking risk in the business process. The banking market in Central and South-Eastern Europe is relatively weak and underdeveloped compared to the European Union. At the beginning of 2005, a large number of foreign banks appeared in the SEE region interested in entering the respective financial market. It should be noted that in the last two decades of the 21st century, the leading groups of EU banks in the CEE region have experienced expansion, as can be seen from the size of banking assets, capital and profitability of banks. Analyzes of the banking sector show that more than $70 \%$ of the banking market in Southeast European countries is influenced by foreign banking groups.

With the advent of the global financial crisis, the activity of the leading banks from the European Union and their entry into the financial market of Southeast European countries decreased. The trend is still present, as the number of attractive banks that could be acquired through fusion and acquisition has decreased in the banking market of countries in transition. Similarly, overall economic growth in the financial market of transition countries has slowed, so that the liquidity deficit is often present in the financial sector. A positive trend has been present in recent years in the share of GDP and the share of total assets in the structure of GDP. Sustainable development can only be achieved through the joint action of the banking sectors of the Central and South-Eastern European countries. 


\section{REFERENCES}

Vunjak N., Ćurčić U. \& Kovačević Lj. (2013). Corporate Banking, Proleter Bečej, Faculty of Economics Subotica.

Cocris V. \& Nucu E., (2013). Monetary policy and financial stability (empirical records from Central and Eastern European countries, Baltic Journal of Economics 13 (1), (75-98).

Koch W. T., \& MacDonald S. S., (2003). Bank Management, Thomson - Western, New York.

Pere, E. (2015). The impact of good governance in the economic development of Western Balkan countries. European Journal of Government and Economics, Volume 4: 25-45, Retrieved from http://www.ejge.org/index.php/ejge/article/view/59/52.

Vunjak N., Radović M., Vitomir J. \& Štrbo S. (2019). Corporate Finance, IRC - Center for Economic Research Subotica, Modern Business School Belgrade (MBS).

Curcic U. (2003). Managing Bank Growth and Performance (Strategic Management of Bank Value and Performance Growth), Mladost Holding, Color Print, Loznica.

Achim, V., Borlea,N.,\& Mare,C. (2015) Corporate governance and business performance: evidence for the Romanian economy, Journal of Business Economics and Management, ISSN 1611-1699 / eISSN 2029-4433.

Sherstnev, M. A. (2019). World Economy, Economic Science, and Economic Policy: What Comes After the Crisis. In Sustainable Growth and Development of Economic Systems, Springer, Cham (87-100).

Andries, A.M.(2011) "The Determinants of Bank Efficiency and Productivity Growth in the Central and Eastern European Banking Systems", Eastern European Economics,49(6), (38-59).

Dragosavac M. (2013). Impact and Consequences of the World Economic Crisis on Macroeconomic Factors in Central and Southeastern Europe (International Conference), University of Business Engineering and Management, Banja Luka.

Andries A.M. \& Căpraru B., (2012) “Competition and efficiency in EU27 banking systems”, Baltic Journal of Economics 12(1), (41-60).doi: 10.1080/1406099X.2012.10840510.

Košak, M., Zajc, P. \& Zorić, J. (2009) Bank efficiency differences in the new EU member states ",Baltic Journal of Economics, 9:2, (67-89).

Dragosavac M. (2019) Business performance effects on the non-performing loans (npls) level in the CEE banking sector, 5th International scientific conference corporations as multidimensional actors/ entities, University of Novi Sad, Faculty of technical sciences (174-186),

Barth R., Caprio G. \& Levine R.,(2004)" Bank regulation and supervision: What works best?," Journal of Financial Intermediation, Vol. 13, (205-248),doi:10.1016/j.jfi.2003.06.002,.

Buterin V.; Škare, M. \& Buterin, D. (2017). Macroeconomic model of institutional reforms 'influence on economic growth of the new EU members and the Republic of Croatia. Economic Research Економска истраживања, 30, 1: (1572-1593).

Poghosyan, T. \& Poghosyan, A.(2010) "Foreign bank entry, bank efficiency and market power in Central and Estern European Countries",Economics of Transition, 18, No.3: (571-598). doi: 10.1111/j.1468-0351.2009.00378.

Pervan M., Pelivan I., \& Arnerić J.(2017) "Profit persistence and determinants of bank profitability in Croatia," Economic Research- Ekonomska istraživanja, Vol. 28, No. 1, (284-298). doi link: http://dx.doi.org/10.1080/1331677X.2015.1041778.

Garciya-Marco T. \& Robles-Fernandez M.D.(2013) "Risk-taking behavior and ownership in the banking industry: The Spanish evidence”, Journal of Economics and Business, Vol. 60, no.4, (332354) doi:10.1016/j.jeconbus.2007.04.008,2013.

Babihuga R.,(2007) "Macroeconomic and financial soundness indicators: An emperical investigation”, IMF working paper, no.115, (1-32).

Barjaktarović, L., Paunović, M. \& Ječmenica, D. (2013) "Development of the banking sector in CEE countries - Comparative analysis", Central bank of Montenegro, Journal of Central Banking Theory and Practice, Vol.2 No.1. Montenegro. 
Cocris V. \& Nucu E., (2013). Monetary policy and financial stability (empirical records from Central and Eastern European countries, Baltic Journal of Economics 13 (1), (75-98).

Dmitrovic M., Dobrota M. \& Knezevic S.,(2016) "A statistical approach to evaluating bank productivity”, Management, 2016/75, (47-56) doi: 10.7595/management.fon.2015.0010.

Raszkovski A. \& Bartniczak B. (2019). Sustainable Development in the Central and Eastern European Countries (CEECS): Challenges and Opportunities, Sustainability ,Faculty of Economics, Management and Tourism, Wrocław University of Economics, Poland.

Laidroo L., Männasoo K.,(2014) Perils of excessive credit growth: evidence from 11 new EUmember states", Baltic Journal of Economics, 1-2, (17-34).

Mano-Bakalinov, V. (2016). Trade liberalisation and economic growth in Macedonia. South East European Journal of Economics and Business. Volume 11 (2), 48-60. doi: 10.1515/jeb-2016-0010 Central Bank Publications of the analyzed countries (Slovenia, Slovakia, Czech Republic, Poland, Hungary, Croatia, Bulgaria, Romania, Serbia, Bosnia and Herzegovina, Montenegro, Macedonia and Albania) (Time period 2008-2018).

Arestis, P., Ferrari Filho, F., \& Terra, F. H. B. (2018). Keynesian macroeconomic policy: Theoretical analysis and empirical evidence. Panoeconomicus, 65(1), 1-20.

Stanić. S., \& Račić Ž., (2019) Analysis of macroeconomic factors effect to gross domestic product of Bosnia and Herzegovina using the multiple linear regression model, Economics - innovation and economic research, Vol 7, No 2, (91-97) ISSN 2303-5013. Available at: <http://economicsrs. com/index.php/economicus/article/view/192>. Date accessed: 13 may 2020. doi: https://doi. org/10.2478/eoik-2019-0022. 